\title{
Governing by means of sport for social change and social inclusion: demarcating the domains of problematization and intervention
}

David Ekholm

The self-archived postprint version of this journal article is available at Linköping University Institutional Repository (DiVA):

http:// urn.kb.se/ resolve?urn=urn:nbn:se:liu:diva- 144218

N.B.: When citing this work, cite the original publication.

This is an electronic version of an article published in:

Ekholm, D., (2018), Governing by means of sport for social change and social inclusion: demarcating the domains of problematization and intervention, Sport in Society.

https:// doi.org/ 10.1080/ 17430437.2017.1417986

Original publication available at:

https:/ / doi.org/ 10.1080/17430437.2017.1417986

Copyright: Taylor \& Francis (Routledge) (SSH Titles)

http:/ / www.routledge.com/ 


\title{
Governing by means of sport for social change and social inclusion: Demarcating the domains of problematization and intervention
}

\author{
David Ekholm, Linköpings universitet
}

\section{INTRODUCTION}

In recent decades, increasing attention has been paid in social policy to the reputed benefits of youth sport participation (Coalter 2007; Houlihan, Bloyce and Smith 2009; Silk and Andrews 2012). Practices using sport as a means of responding to social problems have emerged globally (Coakley 2011b) and, to situate this examination, in Sweden as a means of promoting a wide range social objectives, for instance social change and inclusion (Ekholm 2017a, 2017b; Ekholm and Dahlstedt 2017; Fahlén and Stenling 2016; Norberg 2011; Österlind 2017; Stenling 2015).

In this article, a distinct sport-based social intervention (the Sport Programme, SP), in a mid-size Swedish city, targeting social problems, such as crime and social exclusion are examined. The program resides primarily in a disadvantaged suburban area and is carried out in a public-private partnership. The intervention was initiated and is funded by municipal agencies (and to a minor part by sponsors), managed by a social entrepreneur and performed by coaches affiliated with the entrepreneur in cooperation with local schools and sport associations. Sport practices, in all eight different sports, are carried out in close collaboration with local schools for children in the lower grades. The program aims, according to the social entrepreneur's Articles of Association, to "reach out to children who are not active, involve them in sport, work with social issues, integrate, gather up all youths in the risk zone, coach, educate them to a better future".

The ambition of the examination is to analyse how representatives of the program conceive of the social change promoted and the social problems responded to. Specifically, focus is on how social problems are conceived of in relation to how the intervention and the technologies of governing imbued are promoted as solutions, forming certain domains where intervention and governing measures can take place. Accordingly, the aim is to examine how the domains made ready for intervention and the governmental rationality constitutive of the intervention are formed. By examining statements made by representatives of the intervention, the article outlines the social domains where social change and governing is presumed to take place and it makes clear how the formation of and particularization of certain domains make up a characteristic feature enabling sport to be articulated as a means of social objectives. The analysis is approached from a governmentality perspective (cf. Bacchi 2009; Dean 2010; Rose 1999).

In contemporary society, sport has a profound and intriguing cultural significance (Hartmann 2016). Sport practices are widely associated with deep-seated beliefs about the embodiment of moral virtues as well as ideals of fair play, competition and meritocracy vital for our selfunderstanding of modern and liberal society. Underscoring the popularity of youth sport participation, such notions achieves a particular significance with respect to formation of active citizenship and community. From another viewpoint, sport is associated with notions about play and games, and most people see sport practices as merely amusement and diversion. In this sense, sport becomes an inoffensive container of particular moral values. In addition, there are prominent notions that sport and politics are separate things and that these fields should be made distinct from each other. Consequently, sport is culturally positioned both as a means of policy objectives and at the same time as something which needs not to be taken too seriously or to be mixed up with politics. It is in this contested and paradoxical terrain the symbolic power of sport in society are formed and configured as a productive political force and as a tool for providing welfare (Hartmann 2016). 


\section{RESEARCH CONTEXT}

Notably, sport practices are embedded in cultural and social contexts; they imbue political rationales. Here, sport is introduced and situated in relation to welfarist and post-welfarist social policy as a means of responding to social problems.

\section{Governing from 'the social point of view'}

Responding to social problems is generally seen as an objective for the welfare state (e.g Parton 1996). When sport is being used as a vehicle to facilitate goals such as social inclusion, sport needs to be scrutinized as a tool for welfare provision and social work. Social problems, social change and social inclusion as well as social policy and social work presuppose a certain conception of 'the social' (cf. Deeming 2016; Donzelot 1988; Garland 2014; Rose 1999). 'The social' domain is characterized by collective solidarity and security - formed beyond the family and religious or local community; moreover, the emphasis in welfare provision is not just on individual responsibility but also on the notion that people are interdependent in their exposure to social problems (Donzelot 1988; Rose 1999). In welfare states in general, and particularly in the Swedish welfare state known as part of the social-democratic welfare regime (Esping-Andersen 1990), the notion of 'the social' domain is of central importance (Donzelot 1988, 1991). Welfarist social reforms are destined to target broad collectives and ultimately "society as a whole" (Donzelot 1991, 173).

However, governing from the social point of view has been seriously contested in Western welfare states lately and more advanced liberal forms of governing welfare have been influential (Deeming 2016; Rose 1999) not least, with respect to Sweden and the social-democratic welfare regime (Larsson, Letell and Thörn 2012). This development has involved less ambitious risk protection schemes focusing on individual risk management, selective outreach in welfare interventions and involvement of private agencies in the welfare mix, for instance through public-private partnerships (Webb 2006). Moreover, innovative and unconventional arrangements for responding to social problems have emerged (Webb 2006) - for instance, sport for social objectives (Silk and Andrews 2012) - in response to challenges of urban segregation, social exclusion and crime highlighted in contemporary social policy (Ferguson and Lavalette 2013). In concomitance, confidence in social and broad political reform throughout Western and liberal societies are decreasing. Liberal universalism and hegemony have obscured questions of structural inequality and social conflict from the political discourse. Structural and political concerns are more and more articulated in terms of moral and individual problems. This has created a post-political condition, where less social concerns are conceived of as political and, consequently, political conflicts are blurred (Mouffe 2005).

\section{Sport and welfare in Sweden}

In Sweden, sport have historically been conceptualized and promoted in relation to the welfarist agenda (Bergsgard and Norberg 2010) based on implicit expectations to provide with among other things public health (Österlind 2017), integration and democratic socialization (Norberg 2011). Formally, the sport movement as part of the civil society have been autonomous from the state but at the same time dependent upon subsidiaries (Bergsgard and Norberg 2010). However, in the recent decades, sport associations have been increasingly seen as an instrument in the realm of social policy. By means of governmental programs like The Handshake and The Sports Lift in the early 2000's, with dramatically increased public funding, demands on sport practices to provide for social policy objectives were formalized (Fahlén and Stenling 2016) reconfiguring the relation towards more of an "explicit contract" (Norberg 2011). Today, public and governing agencies on both national and local levels increasingly conceive of sport as a means welfare provision and programs are initiated using sport as a means of a range of welfare objectives (e.g. Ekholm and Dahlstedt 2017; Stenling 2015). For instance, the Swedish government have 
specifically directed major funds to the sport movement and to sport programs for contributing to integration of refugees, following large in-migration to Sweden just the recent years (Fundberg 2017).

\section{The potential of sport-based interventions in welfare provision}

The relation between sport and social outcomes have been thoroughly scrutinized in research (Ekholm 2013). Even though sport has potential benefits, influential research suggest that notions of sport's social utility have been "uncritically determined" (Morgan 2013, 831) and that they rest on "deeply entrenched storylines" (Houlihan, Bloyce and Smith 2009, 5) and "lack [of] clarity and intellectual coherence" (Coalter 2015, 20). Sport, as such, does not seem to have inherent qualities suitable for achieving welfare objectives - it all depends on how practices are performed (Brettschneider 2001; Coakley 2011b; Verdot and Schut 2012). Though, potential benefits have been highlighted, and while sport has been observed as a means of diversion (Nichols 2007), this article focuses on sport as a means of social change (cf. Ekholm 2013). In this sense, research has spotlighted number of ways that sport practices facilitate processes of change.

First, participation in sport may provide with empowering competences to be active, responsible and participant in society as well as socially mobile (Coalter 2007; Lawson 2005). The pedagogical focus here aligns with ambitions to build "active citizens" (Green 2012). In relation, selfconfidence, self-esteem and self-control could be noted as potential outcomes of sport-based interventions (Fraser-Thomas, Côté and Deakin 2005; Nichols 2007). Second, sport settings are observed as arenas where young people meet with and develop relations to youths from other social backgrounds (Nichols 2007), with social projects staff (Andrews and Andrews 2003), with sport coaches and positive role models (Richardson Jr. 2012) as well as with parents and other adults (Fraser-Thomas, Côté and Deakin 2005). In relation, sport could be viewed as a hook for reaching out to young people in exclusion or to enter environments that would otherwise not be accessible and engage youths in socialization and in positive social relations (Crabbe 2007; Nichols 2007). Third, in Crabbe's (2000, 390) words, sport-based interventions are "about community development in a real sense, since it is about developing relationships with people on the basis of trust and mutual understanding". Such relations and participation in local voluntary associations may provide access to social networks and social capital (Harvey, Lévesque and Donnelly 2007) and contribute in forming a vivid civil society (Lawson 2005). Additionally, public-private partnerships mobilising civil society is viewed as an important potential (Parnell et al 2015) highlighted particularly in deprived neighbourhoods seen to be in need of civic activity and community (Dacombe 2013). Not least has this been the case in relation to integration (Agergaard and Michelsen la Cour 2012). Here, sport may congregate a kind of managerial social entrepreneurialism (Cohen and Peachey 2015; Sherry, Schulenkorf and Chalip 2015) and involvement of commercial actors (Theebom, Haudenhuyse and De Knop 2010).

However, it was noted that sport-based interventions have only a limited scope when it comes to taking action against or changing the fundamental social conditions in relation to structural segregation and social problems (Coakley 2011b; Coalter 2015; Hartmann and Kwauk 2011). There is, moreover, often exaggerated beliefs that youth sport participation leads to social mobility (Coakley 2011b; Spaaij 2009). Such beliefs, rather, serve to conceal the complex causes of the problems and the social and economic inequalities in society which create social exclusion (Coakley 2002; Hartmann and Kwauk 2011). Even, it is suggested that following increased structural inequalities and reinforcing dynamics of social exclusion in Western societies as well as "within a [political] climate of austerity, sport-based social inclusion schemes are likely to become wholly inadequate in the face of exclusionary forces such schemes envision to combat" (Collins and Haudenhuyse 2015, 5). 
Seeing that sport have emerged as a vehicle for social policy objectives, critical research is sought after (Coakley 2011a, 2011b, 2015; Coalter 2015) specifically focusing on the ideological implications for welfare provision (Heinemann 2006). Based on these observations, it is critical to scrutinize and problematize the outreach and domains of government construed in relation to sport-based interventions, to situate the promotion of sport-based interventions in relation to social policy development, and, accordingly, to examine both the discursive underpinnings enabling articulation of sport as a vehicle for social policy objectives and the discursive effects such articulations may have (cf. Bacchi 2009).

\section{THEORETICAL FRAMEWORK}

The empirical materials examined comprises of statements articulated by representatives of the program about sport as a means of responding to social problems in general and about the particular intervention in specific. The statements analysed are conceived of as discourse producing objects such as social problems and social policy solutions (cf. Bacchi 2009). From this point of view, the processes of constructing discourse about problems are called problematization (Bacchi 2009; Foucault 2004). The term spotlights that social problems are constructed in social process, as objects and conditions in need of change. In terms of discourse they become visible, accessible and ultimately governable in a certain way; yet, the representations of social problems are intertwined with and constituted by the policy measures, the governing technologies and even solutions, aligned (Bacchi 2009). Technologies of governing are the measures of social policy solutions undertaken against and intertwined with problematizations, aiming to impose a certain form of social change (Rose 1999). In brief, governing refers to actions aiming to "to structure the possible field of action of others" (Foucault 1982, 790), to shape the actions, behaviours and even subjectivities - the conduct - of others (Foucault 1991). The ways of conceiving of the relation between problematizations and means of governing as well as with the social policy objectives reached for are called governmental rationality (Rose 1999).

In this article, focus is on the domains of intervention formed in relation to the governmental rationality (cf. Rose 1999). Domains are discursive formations where problematizations and technologies of governing intersect. They are the "abstract spaces" (Rose 1999, 31) formed to host certain problematizations and where governing technologies and means of social change can be performed (Dean 2010). Forming these abstract spaces, these domains, means to make them a container of problematizations and a target of responding and governing interventions; it involves animating certain aspects of society and human life in a certain way making them distinct and possible to be acted upon (cf. Foucault 1980). Rose $(1999,36)$ compares the construction of governable domains with the efforts of a cartographer: creating spaces and objects as presentable, representative and visible - controllable, as well as "docile and amenable" for governing social change. In the sense that discourses are understood to be performative, domains do not pre-exist in absence from problematizations and governing technologies, they are constituted by them. Accordingly, statements representing domains in a certain way constitute knowledge about the domains making them ready for a certain kind of intervention and governing technologies (Rose 1999) - in this sense, statements imbue a performative force. Seeing that domains are discursive formations does not make them any less real than anything else; they become real as they acted upon (cf. Foucault 1980). To illustrate, the domain of 'the social' touched upon before has had a great impact on the emergence of welfarism and modern social work and welfare interventions, because it is a domain where problems are socialized and governing measures targeting the wider collectivity of a population could be performed (cf. Dean 2010; Donzelot 1988, 1991; Rose 1999). 


\section{EMPIRICAL MATERIAL AND PROCEDURES IN ANALYSIS}

The statements analysed were articulated in interviews with representatives of the program, in newspaper article quotations and in official documents. Two local policy makers, one civil servant, the social entrepreneur and two affiliated sport coaches were interviewed. Municipal Councillor 1 chairs the Municipal Executive Committee and previously chaired the Childcare and Education Committee. Municipal Councillor 2 chairs the Childcare and Education Committee and is a member of the Municipal Executive Committee (both councillors represent the ruling Social Democratic Party in the municipal council). The senior Civil Servant answers for the municipality's role in relation to the SP. The three representatives were carefully selected for this analysis because they hold key positions in social policy formulation and administration. The social entrepreneur manager is responsible for setting up and planning the activity. He is also involved in carrying out the sport practices. He is moreover the centrepiece of the organisation: collaborating with the policy makers and the civil servant, engaging in contacts with the local enterprises and merchants, with national social investment programs as well as with other potential sponsors and partners, above leading the affiliated coaches. Coach 1 is a successful athlete in his sport employed in the program as a youth sport coach. Coach 2 is a former athlete studying to become a leisure and recreation leader and employed by the entrepreneur manager to lead the sport practices in the program. The three on-site leaders are men between 20 and 30 years of age. They were either born abroad or have immigrant parents and they grew up in the local suburban area where the SP resides or in similar urban areas in Sweden. The three of them lack formal social work or pedagogical training or other higher education.

Interviews with the social entrepreneur manager took place in an office building nearby the site of the sport practices. The manager was interviewed twice. The coaches were interviewed on the site of the Sport Program and the Municipal Councillors as well as the Civil Servant were interviewed at City Hall. Each interview took between 45 and 120 minutes. Interviews were guided by the respondents' own descriptions and presentations of the program and did not follow a predefined schema. Statements made in interviews are shaped by the situation in which they are articulated (Cruickshank 2012), and accordingly, serious efforts were made to minimize the interviewer's influence. For instance, the interviewer initiated various subjects, asking the respondents to describe aspects of the practices. This could be assessed in transcripts that generally contain long narratives rarely interrupted by the interviewer. Included in the analysis, with respect to the SP, were also explicit quotations in 25 local newspaper articles articulated by respondents, the social entrepreneur's public presentation of the program and the official Articles of Association were obtained from the Swedish Companies Registration Office. The bulk of narratives and statements about sport as a means of responding to social problems were transcribed verbatim and analysed as discourse.

Analytically, it is the concepts of governmental rationality, involving problematizations, domains and technologies of governing, that inform the examination. The theoretical framework and concepts presented are used as a toolbox, enabling interpretation and for seeing patterns and regularities, for providing context and for tracing the governmental rationality (Rose 1999). In practice, statements examined were thoroughly read, scrutinized and sorted into broad categories of problem representations and solutions (technologies of governing). Based on this categorization the analysis proceeded in outlining the rationales interlinking certain problematizations with means of responding technologies. Here, the domains of intervention identified could be sketched out. Accordingly, themes such as problematizations, domains and technologies of governing - and, not least, governmental rationality - driving the analysis, were theoretically derived. Conclusively, the statements were sorted based on four main domains of intervention and analysed in terms of how each domain were problematized, made ready for intervention and how governing social change were conceived of in relation. 


\begin{abstract}
ANALYSIS
In the analysis, four domains of intervention are outlined. This means that four distinct discursive formations - 'the self, 'the family', 'the community' and 'the place' - are problematized and formed as objects and domains of social change and of governing intervention. Each domain is problematized in terms of lack and otherness. In relation, the domains are constructed as locations where solutions take place. The rationality of governing intervention forming social change could be approached to varying degrees in terms of future, morality and adaptation. This means that governing technologies aims at the future conduct and disposition of the domains, focusing on the moral regulation and on adaptation to dominant norms of the included society. The domains outlined should not be perceived as disparate from each other, but rather as interwoven dimensions where the problematized effects of social segregation are located in statements and pinpointed as particular formations of otherness and exclusion.
\end{abstract}

\title{
Governing 'the self'
}

The sport practices are thought to contain informal means of social pedagogy. The youths are subjects of learning, socialization and empowerment. They are believed to be equipped with certain competences needed to manage in society. The youths are viewed to be lacking capacities to master their own lives, to reject group-pressure and to make the right choices in life. In many ways, the lack of capacities is associated with otherness and these lacks are attributed to their position of social exclusion; it is not a general problem of youths, but rather, a problem of youths in excluded positions.

I think, generally, that it is great to do sports... and it is a way to get away from these bad things. I, like... myself... grew up in a rough area and a rough society and... so, I know and I have seen many people get in trouble. And this is a good way to... like... reach out to and gather kids and youths and to get them to... yeah, feel like they have different tracks to choose. Like, good tracks instead. [...] There are many who... yeah... end up on the wrong side and that is the purpose of [the SP] also to try to get the most of them... or them with the capacities, to get them to think in a different way. [...] I know that if you are sensitive to fall for group pressure, or like... and not being able to decide for yourself or to be independent, then it is easy to end up there. (Coach 1)

In the above excerpt, the governing rationale concern changing the conduct of individual youths, their actions, behaviour and ways of thinking (their mentality and subjectivity). Here, learning to think right, to make the right decisions and ultimately to be responsible for choices made is the central pedagogic rationale. The competences and powers that are on offer are designed to make it possible for them to navigate away from problems - to be responsible for, as well as to be the guarantor of, their own security and welfare. Here, focus is on how sport may contribute motivational powers of self-esteem and self-confidence - something that is presumably lacking in the targeted youths - so that they themselves could learn to navigate in and adapt to a society full of risks, choose the right track and succeed in taking responsibility for their own lives. 'Choosing' and 'deciding' indicate that the governmental rationality is, above all, about learning to be active and responsible. In this way, welfare is represented in the form of individual morality - to make the right decisions, to be autonomous and to choose the right track. In the following excerpt, the importance of moral activation is stressed:

We want residents who are active in one way or another and not passive... passivized. It is essential that we have young people who find an interest in life that is positive and so that they can engage in something else. Otherwise, there are so many other forces that knock on and want to pick you up as a supporter in one way or another. [...] We see these criminal gangs standing and recruiting, and the boys run around the shopping malls and... where the youths meet. And if it is like... if you don't find friends, a community, and are liked and loved in a positive environment, you will sure be in a non-positive kind of... in a gang like that. And we want to 
counteract that and then this is one step, promoting the associations and community so that the kids get active there. (Civil Servant)

Here, sport becomes the equivalent of moral activation, above autonomy, which is the alternative route in relation to the forces of deprivation and criminality that is a risk in the suburban area. Community within civil society associations is stressed as a better alternative to the feelings of reciprocity that could be sensed also in destructive environments and in gangs. Individual morality means autonomy and self-control, in terms (not least) of not being a burden to the rest of society. It is the power of 'the self' that guarantees future prosperity and autonomy. In the following excerpt, a policy maker articulates the distinction between being dependent upon welfare state institutions and providing for one self and for being able (and enabled) to decide over one self.

Doing good means that you feel that I... I am the master of my own life, that I can make my own decisions. It is not the employment office or the social insurance agency or the employer or mom who makes all decisive decisions and who decides exactly what to do, but I can choose for myself a satisfying life. I can affect my life, I have the power over my own life. (Municipal Councillor 1)

Here, to be responsible equals to not let others be the agents in one's life and succumb into passivation and to not be a burden to society. Shaping youths prepared with motivational powers - who are self-aware, aware of their freedom, their opportunities (as well as obligations) and responsibilities to choose the right track and take advantage of the possibilities by navigating among and escaping risks and problems - should be understood as a form of citizen engineering. In the above excerpt, "power" is stressed as the most central resource strived for. The educational engineering, ideally, aims to produce youths who are "masters of their own lives", activated and empowered with forces that enables to "make [their] own decisions" and provide for one's own security and welfare - that is youths that are in power of their own lives, who are not dependent on 'the social' forms of welfare provision issued. The question posed, here, is really were power and therewith responsibility for welfare and risk-management ought to be located: on ground of the activated and responsibilized 'self' or on ground of 'the social' kind of welfare provision and institutions collectivizing risk. In this sense, 'the self' constitutes the discursive formation in which problematizations of individuals' actions, behaviours and ways of thinking are recognized and become a matter of social change. The technology deployed, which is highly sophisticated, incorporates elements of moral self-reflection, which means learning to conceive of oneself as a moral subject, as governable and as a domain in which to carry out morality formation. The youths should learn how to reflect on themselves as targets of social change so that they can govern change through active, responsible choices. The rationales of pedagogy and learning in relation to formation of subjectivity and development of skills and competences, stresses that the intervention is aimed at future conduct and ways of action, to regulate events in an uncertain future.

\section{Governing 'the family'}

Notably, the sport-based intervention is described as a strategy to reach out to the families and parents of the youths. Families are targets of social change in terms of how parents are problematized and seen to be lacking certain competences and habits of involvement in their children's life as well as with concern to how parents are modelling the conduct of their children. According to the statements analysed, youths residing in the suburban area lack of support from parents and, in accordance, the intervention - the coaches and manager - could possibly compensate for that.

['The place'] is such an area where there are many people who come from other cultures where they do not have these traditions, Swedish association traditions, and there are much fewer 
associations here. If you cross the expressway then you have [the area of inclusion], which has one of the largest sports associations in the district, with leaders who are committed and also competent, that are proficient. And you have, like parents, who contribute a lot, so that's just... that's obvious. They are doing a great job. But in ['the place'] you do not have that. (Municipal Councillor 2)

Here, parents are problematized in terms of their poor contribution to their children's leisure activities. This is explained as the cause for the problems of the local sport associations - a lack of leaders and parental assistance - resulting, ultimately, in the cancellation of youth teams in the club. Parents lack knowledge about associational culture and civil society - and parental involvement is emphasised as fundamental for the youth sport practices. In addition, reaching out to the parents means that families and parents could get involved and learn how sport and society in general works, to meet with other people of the included society and, consequently, be equipped with competences needed to participate and contribute.

In one instance, by involving children and youths in sport participation, the intervention potentially becomes a means of reaching out beyond the children and into their families and influence the parents. This way the intervention is ascribed a farther outreach into the lives of families and parents. Children and youth are formed as a mediate to intervene in the 'the family'. In another instance, reaching the parents and approaching them (as in the following excerpt), emphasising that their conduct influences their children's way of life, means that it is the parents (and 'the family') that are construed as a mediate to influence the conduct of children and youths. In the following statement, the social entrepreneur manager problematizes parental involvement in terms of bad conduct - something that stresses the importance of influencing the parents in order to reach the conduct of the children and youths in the suburban area. In both instances, 'the family' is problematized and ascribed as a potential space for social change.

Then, we have the parents that... when we are out in the summer, we meet parents sitting on the benches just by the sports ground. They are having a cigarette, they smoke, they litter and leave trash, so it's even harder to become the good role model for his children and to explain that... ok... so what we have as our most important task is that as soon as we see someone smoke, some parent who comes there... straight away, it is important to create relations and to create contacts, and just say that "yes, we are here for your kids, we offer this, everything is free". [...] And also to comment on that we have as a rule that when we are here, we don't want anyone to smoke because it gives bad signals to the kids and you don't want your child to be a criminal or this and that... And some parents follow straight, and some don't give a shit... "ok, but if you want to be here, these are the rules". And because we all know each other well and that it is the right person who talks to the parents and that we bring this about. [...] But if you can properly express to him that if you smoke, this can actually mean that the children adopt. Then, if you communicate properly, you can also get the parents to understand that... alright, I won't do that. (The Manager)

Here, the importance of role models within the sport-based intervention is emphasised, guiding the conduct of children and youths. In relation to them, parents are problematized in terms of moral shortcomings and bad conduct. Parents misconduct, in turn, complicates the pedagogic and modelling routine of sport coaches as positive role models. Therefore, forming genuine relations and personal bonds between the coaches and the parents are seen as a precondition for reaching out to them and consequently for influencing the children. Because both coaches and parents in the excerpt are noted to be part of the same community - the coaches are familiar with the culture and they are the right persons to approach the parents - such personal and moral bonds may be established and acted upon. The coaches are the right persons exactly because they are well known and kitted with authenticity and a personal biography (not least in terms of a successful sport career) relevant for life in 'the place', they belong to 'the community'. If these conditions are met, children and youths could potentially learn, their conduct may be successfully modelled, and future risk of criminality and other delinquent behaviours may be counter-acted 
and prevented. Clearly, the conduct promoted stresses ideals of diligence and obedience to the simple rules and restrictions established within the program, for example non-smoking and nonlittering (which are viewed as a first step on the path towards future more advanced misconduct and criminality). By means of reaching for the conduct and moral fabrics of parents, social change could be attained - and in this endeavour 'the family' are constructed as a site of problematization and as a subject of potential social change.

\section{Governing 'the community'}

In the overwhelming part of the statements analysed, society is characterised by segregations and conflict rather than social solidarity and community. Moreover, the conflicts are conceived of as constituting a threat for the future; accordingly, measures need to be undertaken. According to Municipal Councillor 1, the segregation, "social divides... culturally and ethnically", today "will cause greater tensions if we do not manage to create fair conditions". In this sense, sport represents an alternative to segregation and conflict: it represents integration and community. In a previous excerpt, the social entrepreneur manager described how 'the community', in terms personal relations and familiarity was a key to reaching out to parents and thereby influencing the children's conduct. What is repeatedly stressed here, is precisely, the idea of authentic personal and moral relations between persons with a shared background and sense of common identity. Community, in this sense, refers to the moral bonds in gemeinschaft between people and agencies in society (in contrast to the instrumental and indirect bonds attributed to 'the social' domain). The intervention is assumed to operate on 'the community' domain in two instances. First, it uses the direct personal relations between people based on common identities and shared experiences. Second, it resurrects the moral bonds in partnerships between different actors and welfare providing agencies.

When children get in contact with the good role models and with the associations, the credibility become stronger when they know that they are here for you. That way, they will see that "I developed so strong bonds with the coach and I think he is a great leader, therefore I will go to the after-school sport activities because the coach is also there..." and this makes the children feel safe and makes it more credible... because you make sure to follow the kids. (The Manager)

In the first instance, the sport-based community is founded on individuals' personal and reciprocal relations and moral responsibility for each other. They presumably identify with each other and share common interests. Genuine and authentic relations in sport between youths and role-modelling coaches are highlighted in the discourse and it is through sport practices that role models can reach out to youths. By sharing a common identity and experience, this kind of conductor of social work could be described as credible and as a potential facilitator of social change. This is underscored by the manager, when remarking that the "coaches have a deep understanding of the targeted population and [they] often come from that group" and that this makes them "credible role models who demonstrate that it is possible to change one's future". Likewise, Municipal Councillor 2 means that the coaches' backgrounds are "extremely important in this meeting [and that] they have an understanding of the problems in another [experiencebased] way". Additionally, he believes that it is "hard to reach out to certain groups in our structure [with] professionals and civil servants working on our hours [and] sometimes more is needed" in order to reach the youths identified as being at risk of future misconduct. Hence, the community base is what is "more" and "needed". The coaches have no specific professional skills, but they have experiences and an identity that make them part of 'the community', and this competence and qualification is what is sought after in the conductors of social work. These competences and belonging to 'the community' are seen to be essential when it comes to meeting with youths and with their parents. Importantly, the human and moral kind of community that is animated is different from the professionalized and politicized social domain of instrumental and impersonal relations that presumably constitute the basis of public welfare efforts. 
In relation, the importance of community role models in reaching out to youths and into their families (and, as will be explored further, reaching out into the encapsulated area of exclusion) is of a certain relevance for analysing how the residents are made distinct from the rest of the social collective. Implicitly, resident youths cannot be reached by professional welfare interventions and traditional social work; nor is it assumed that they can be reached by traditional Swedish voluntary associations. In this sense, they are animated as being unknown to professional social workers and public welfare administrators given that the population targeted as being at risk does not share a common history, experiences or identity with professionals and administrators.

Moreover, they lack an understanding of Swedish voluntary sport organizations and therefore cannot arrange their leisure activities according to the established formula of Swedish sport and civil society. The youths targeted are constructed as different, deviant and unknown; their actions, behaviours and ways of thinking could not be sufficiently assessed by professionals, but their characteristics and conduct could be recognized and understood by the community role models who share identity and history. This is further explored in the next section. Moreover, belonging within 'the community' could be viewed in relation to the dangers of dependency in relation to 'the social' welfare institutions articulated and analysed previously. In this discourse, the personal relations of civil society are not associated with dependency and subjugation, but rather with authenticity, moral activation and inclusion by means of free will and autonomous relations. In other words, when as 'the social' kind of welfare is associated with dependency and passivation, 'the community' kind of welfare is associated with belonging and moral activity.

In the second instance, community could be formed in terms of relations between a variety of social actors taking part in social and welfare intervention and by mobilising civil society in public-private partnerships, thus making them part of the moral community responsible for responding to social problems. In the following excerpt, Municipal Councillor 1 expounds on how cooperation with civil society is seen as a key in combating social exclusion and problems.

It is an effort to make civil society... that is sport associations, to make sure that they reach out also to them living in residential areas where we today have low levels of participation. [...] So, associations are important and besides, from a municipality point of view, it requires low efforts to support this. And, also, it is very cost-effective, because if you support and encourage associations, the you get so much back. [...] The reason that we try to steer [the SP] to these areas, is because associations generally don't reach them otherwise. (Municipal Councillor 1)

Here, civil society and sport associations are positioned as a vital part of forming 'the community', one that needs to be supported and encouraged by the public agencies. Not least, civil society and sport associations are described as self-driven and accordingly cost-effective in terms of providing for social objectives. Cooperation between municipal agencies and local civil society actors (and possibly even social entrepreneurs) are associated with a historical tradition in building community. In Municipal Councillor 1's words "schools, associations in collaboration $[\ldots]$ is not really anything new" but something that needs to be carried out "more systematically, goal-oriented and more targeted in areas where we know that the need is the greatest". That is to steer cooperation in a rational and instrumental way targeting the domains (individuals, families and areas) that are in most urgent need of support. Presumably, sport practices and participation are viewed as ideal institutions for enabling community-based cooperation. This is at least in part because the sport setting provides opportunities for the social entrepreneur to establish a platform for reaching out to the targeted youths and to involve "civil society or associations, non-profit organizations" (Municipal Councillor 2) and "other institutions and companies" (Civil Servant) that presumably want to take part in and share responsibility for countering social problems. 


\section{Governing 'the place'}

The geographical dimension of otherness and exclusion has been touched upon in several excerpts already. There are particular conditions framing life in 'the place' that are not asserted in other parts of the city or society in general - for instance, with respect to, immigrant population, lack of autonomy among resident youths, misconduct and crime. Notably 'the place' is problematized as a disparate spatial domain of special needs. In relation, this specific discursive formation is shaped and made ready for governing technologies. Importantly, 'the place' is repeatedly articulated as problematic in two instances. First, the neighbourhood area is animated as being dangerous and filled with risks and social problems. Second, the area is described to be populated by deviant people incapable of managing their lives and welfare. Together, these ways of articulating conditions and life in the suburban area, forms a domain characterized by otherness, deviancy and exclusion.

In the first instance, which have been articulated in a number of statements presented already, dangers, risks and problems are located in 'the place'. A variety of problems and dangers are ascribed to life in 'the place'. For instance, in the words of the Manager, school failure could cause unemployment and when "you have no job... then it's easy to drift into destructive environments and become a criminal". The risks pose challenges to the resident youths that they need to assert and navigate among by means of choosing the right track. In the statements analysed, it is as if drugs, crime and bad things and the exposed conditions of life in 'the place' were natural elements in the social flora of the area, posing challenges to the residents that they need to act upon and in relation to.

In a previous excerpt presented, 'the place' is described as an area of exclusion in relation to a nearby area of inclusion, located just on the other side of the expressway. These descriptions of spatial distinctions, metaphorically drawn in the image of the expressway, spotlight how social problems are located and contained in 'the place'. With respect to the second instance, the area of inclusion is characterized by homogenous Swedish ethnicity, a high standard of living, welladapted and capable residents, for instance in terms of parental involvement and well-managed sport clubs. In relation, 'the place' is described to be lacking all of this. Instead, the residents are problematized in terms of otherness, passivity, unemployment, and hence, need of support. In other words, there are people who are capable of managing their own risk, and there are those who are not well adapted to society and who are incapable of managing risk and providing welfare for themselves and therefore are in need of support and intervention. The latter have poor resources and insufficient opportunities to control their own lives - lives that are exposed and subject to social problems. In these senses, 'the place' is demarcated from the rest of the city and society as particular and deviant. Most explicitly, this is illustrated in another statement by Coach 2, locating "the place' to be "off the map, so to speak". The importance of intervening specifically in 'the place' and targeting the resident population is spotlighted in the following excerpt.

We had these integration projects in ['the place'] where there are many people born abroad and with a foreign background, so that they would make contacts with the Swedish associations and community $[\ldots]$. The kids where given another kind of influences than what was normal here. $[\ldots]$ We saw that we had an integration problem, so to speak. Because there was a division between the neighborhoods and because people like to enclose themselves in these areas and going on with their usual activities. Here, we wanted to bring in something that did not really belong there. (Civil servant)

Here, the divisions between different areas are highlighted and the importance of reaching out into people who allegedly enclose themselves from the rest of society are stressed. According to the civil servant, the intervention provides with influences and practices that are necessary for inclusion; but, that are not usual in 'the place' and not part of everyday life there. The following 
excerpt highlights again the risks attributed to 'the place' and moreover the importance of reaching out to the resident youth.

The idea was to come to their area and to meet them there instead of them coming to meet you [...]. Exposed children... that is youths who easily would end up on the wrong track, in areas that are... suburbs where there is a lot of... where crime rates are high. (Coach 2)

The intervention seeks to reach out and penetrate the borders enclosing and excluding 'the place' from the rest of society, using community based role models with common identities and shared experiences as their special competence in doing social intervention. 'The place' and the population are selected and made distinct from other places and populations. They are assessed as deviant and displaced from the rest of society. In this way, 'the place' and its population (like 'the self and 'the community') are demarcated from society as a whole. From this vantage point, sport practices may be tied to the specific place in two regards: sport practices are performed locally at the local sports ground and gymnasiums, and, the intervention has a local outreach engaging youths in the local schools.

Conclusively, 'the self, 'the family', 'the community' and 'the place' are formed as discursive domains in which certain problematizations are interlinked with responding technologies of governing. The domains are in this sense enacted and animated as a centrepiece of the governmental rationality imbued in sport as a means of responding to social problems. The particular domains are interwoven with each other. For instance, technologies of 'the self' aiming at responsibilisation of youths and their self-management and self-provision of security and welfare are lifted as a response to the risks and dangers attributed to life in 'the place'; moreover, family problematizations and lack of parental involvement are seen in relation to characteristics of 'the place' and counteracted, for instance, by means of developing 'the community'. In this sense, the formation of distinct and made particular domains of intervention illustrate a fragmentation of society as a whole, which is central for the governmental rationality outlined.

\section{DISCUSSION}

In relation to 'the social' domain briefly outlined previously, the sport-based intervention examined delimits its outreach to certain particular domains, which are distinguished and separated in articulations from the normal and included social body. The domains problematized and constructed are made particular from the rest of society based on lack of integration as well as otherness and deviancy from established norms. The kind of social work that can be performed in this intervention by means of sport practices is limited to governing the agency and responsibility of 'the self', the parental involvement and learning of Swedish culture in relation to 'the family', the moral bonds and partnerships of civil society and 'the community' as well as the management of risk and dangers contained in 'the place'. Problems and potential solutions are located to these particular domains, issuing that it is these particular domains that are dysfunctional in an otherwise functional and integrated society.

In many respects, problems are explained as consequences of structural segregations and social conditions beyond the control of individuals, their families and communities themselves, notwithstanding characteristics of the specific locality. Still, it is the domains mentioned that are problematized and attributed as spaces for governing intervention. This could be interpreted as a contradiction. However, this is not necessarily a signal of inconsistency - instead, such way of approaching problems and solutions imbue its own particular rationality. When sport is conceptualized as a means of responding to social problems, it is perhaps not despite the fact that the intervention does not target 'the social' kind of reform, but rather precisely because of this. It may be because sport limits the targets and potential outreach of social change to the particular domains of 'the self, 'the family', 'the community' and 'the place' and thus constitutes a social policy measure that could not possibly impose change or reform on 'the social' domain or on 
society as a whole, that it becomes possible to communicate successfully within the frames of contemporary social policy paradigm. The core idea of promoting a solution that does not actually target the underlying causes of social problems, may be one key success formula of promoting sport as a means of social objectives. In contemporary society, perhaps such notions of sport and social change have a fashionable role to play. As a particular measure, sport illustrates that society as a whole is exempt from problematization; instead, particular deviances can be pointed out and remedied within the frames of the established social order: it is not society that should be reformed - it is particular problematized individuals, families and communities that should reform or adapt. Consequently, the kind of change imbued in the governmental rationality sketched out in relation to the sport-based intervention is built on the notion that major social reforms are neither conceivable or thinkable nor desired.

By means of establishing distinctions between inclusion and exclusion as well as between normality and otherness, and by means of locating both problems and potential solutions to the sites of exclusion and otherness, society as a whole can be left out of problematization. In turn, the formation of certain domains pointed out as excluded and deviant legitimizes and aids in maintaining the social structures that creates the very exclusion. Sport as a means of responding to social problems may, in this sense, be understood in relation to a post-welfarist (cf. Dean 2010) mutation of 'the social' domain, fragmented and particularized, and as part a post-political (cf. Mouffe 2005) frame for interpretation where social order is conceived of as historically and politically fixed (in contrast to contingent) and thus not subject to conflict or social reform. Here, only particular domains can be made subject of social change, separated from (and fragmenting) "society as a whole" (cf. Donzelot 1991). In times when profound social reform seems not to be on the policy agenda, particular (excluded and othered) targets would fit the policy paradigm well. Making the domains of intervention particular would in this sense constitute a discursive premise for intelligibly articulating sport as a means of responding to social problems. Arguably, such discourse enables fragmentation of political government and welfarist social policy reform.

\section{REFERENCES}

Agergaard, S. and Michelsen la Cour, A. 2012. "Governing integration through sports. A case study of civil society involvement in welfare policy". Nordic Journal of Migration Research 2 (1): 2634. doi: 10.2478/v10202-011-0024-y

Andrews J.P. and Andrews, G.J. 2003. "Life in a secure unit: The rehabilitation of young people through the use of sport". Social Science and Medicine 56 (3): 531-550. doi: 10.1016/S02779536(02)00053-9

Bacchi, C. 2009. Analysing Policy: What's the Problem Represented to Be? Frenchs Forest: Pearson.

Bergsgard, N.A. and Norberg, J.R. 2010. "Sport policy and politics: The Scandinavian way". Sport in Society 13 (4): 567-582. doi: 10.1080/17430431003616191

Brettschneider, W. 2001. "Effects of sport club activities on adolescent development in Germany”. European Journal of Sport Science 1 (2): 1-11. doi: 10.1080/17461390100071201

Coakley, J. (2002). "Using sports to control deviance and violence among youths: Let's be critical and cautious". In Paradoxes of Youth and Sport, edited by Gatz, M., Messner, M.A. and BallRokeach, S.J., 13-30. Albany: State University of New York Press.

Coakley, J. 2011a. “Ideology doesn't just happen: Sports and neoliberalism”. Curitiba 1 (1), 67-84. doi: 10.5380/alesde.v1i1.22743

Coakley, J. 2011b. "Youth sports: What counts as "positive development". Journal of Sport and Social Issues 35 (3): 306-324. doi: 10.1177/0193723511417311 
Coakley, J. 2015. "Assessing the sociology of sport: On cultural sensibilities and the great sport myth". International Review for the Sociology of Sport 50 (4-5): 402-406. doi: $0.1177 / 1012690214538864$

Coalter, F. 2007. A Wider Social Role for Sport: Who's Keeping the Score? London: Routledge.

Coalter, F. 2015. "Sport-for-change: Some thoughts from a sceptic". Social Inclusion (3) 3: 19-23. doi: $10.17645 /$ si.v3i3.222

Cohen, A. and Peachey, J.W. 2015. "The making of a social entrepreneur: From participant to cause champion within a sport-for-development context”. Sport Managements Review 18 1: 111125. doi: 10.1016/j.smr.2014.04.002

Collins, M. and Haudenhuyse, R.P. 2015. "Social exclusion and austerity policies in England: The role of sports in a new area of social polarisation and inequality?". Social Inclusion (3) 3: 5-18. doi: $10.17645 /$ si.v3i3.54

Crabbe, T. 2000. "A sporting chance?: Using sport to tackle drug use and crime". Drugs: Education, Prevention \& Policy 7 (4): 381-391. doi: 10.1080/dep.7.4.381.391

Crabbe, T. 2007. "Reaching the 'hard to reach': Engagement, relationship building and social control in sport based social inclusion work". International Journal of Sport Management and Marketing 2 (1-2): 27-40. doi: 10.1504/IJSMM.2007.011388

Cruickshank, J. 2012. "The role of qualitative interviews in discourse theory". Critical Approaches to Discourse Analysis across Disciplines 6 (1): 38-52. URL:

http://www.lancaster.ac.uk/fass/journals/cadaad/wp-content/uploads/2015/01/Volume6_Cruickshank.pdf

Dacombe, R. 2013. "Sports clubs and civic inclusion: Rethinking the poverty of association". Sport in Society 16 (10): 1263-1278. doi: 10.1080/17430437.2013.821252

Dean, M. 2010. Governmentality: Power and Rule in the Modern Society, $2^{\text {nd }}$ edition. London: SAGE.

Deeming, C. 2016. "Rethinking social policy and society". Social Policy and Society 15 (2): 159-175. doi: $10.1017 /$ S1474746415000147

Donzelot, J. 1988. "The promotion of the social". Economy and Society 17 (3): 395-427. doi: $10.1080 / 03085148800000016$

Donzelot, J. 1991. "The mobilization of society". In The Foucault Effect: Studies in Governmentality, edited by Burchell, G., Gordon, C. and Miller, P., 169-180. Chicago: University of Chicago Press.

Ekholm, D. 2013. "Sport and Crime Prevention: Individuality and Transferability in Research." Journal of Sport for Development 1 (2): 67-78.

http://jsfd.files.wordpress.com/2013/12/sport-and-crime-prevention.pdf

Ekholm, D. 2016. Sport as a Means of Reponding to Social Problems: Rationales of Welfare, Government and Social Change. PhD diss.: Linköping University.

Ekholm, D., and M. Dahlstedt. 2017. "Football for Inclusion: Examining the Pedagogic Rationalities and the Technologies of Solidarity of a Sports-Based Intervention in Sweden." Social Inclusion 5 (2): 232-240. doi:10.17645/si.v5i2.839.

Ekholm, D. 2017a. "Mobilising the Sport-Based Community: The Construction of Social Work through Rationales of Advanced Liberalism." Nordic Social Work Research 7 (2): 155-167. doi:10.1080/2156857X.2017.1310127. 
Ekholm, D. 2017b. "Sport-Based Risk Management: Shaping Motivated, Responsible and SelfGoverning Citizen Subjects.” European Journal for Sport and Society 14 (1): 60-78. doi:10.1080/16138171.2017.1284396.

Esping-Andersen, G. 1990. Three Worlds of Welfare Capitalism. Cambridge: Polity Press.

Fahlén, J. and Stenling, C. 2016. "Sport policy in Sweden". International Journal of Sport Policy and Politics 8(3): 515-531. doi: 10.1080/19406940.2015.1063530

Foucault, M. 1980. "Truth and power". In Power/Knowledge, Selected Interviews and Other Writings 1972-1977, edited by Gordon, C., 109-133. Harlow: Harvester Press Limited.

Foucault, M. 1982. “The subject and power”. Critical Inquiry 8 (4): 777-795. URL: www.jstor.org/stable/1343197

Foucault, M. 1991. "Governmentality”. In The Foucault Effect: Studies in Governmentality, edited by Burchell, G., Gordon, C. and Miller, P., 87- 104. Chicago: University of Chicago Press.

Foucault, M. 2004. "Polemics, politics, and problematizations: An interview with Michel Foucault". In The Foucault Reader: An Introduction to Foucault's Thought, edited by Rabinow, P., 381-390. London: Penguin Books.

Ferguson, I. and Lavalette, M. 2013. "Critical and radical social work: An introduction". Critical and Radical Social Work 1 (1): 3-14. doi: 10.1332/204986013X665938

Fraser-Thomas, J., Côté, J. and Deakin, J. 2005. "Youth sport programs: An avenue to foster positive youth development". Physical Education and Sport Pedagogy 10 (1): 19-40. doi: 10.1080/1740898042000334890

Fundberg, J. 2017. "Idrottsrörelsen och samhällsnyttan - fokus på etnisk mångfald och integration". In Idrottens sambällsnytta, edited by Faskunger, J. and Sjöblom, P., 118-130. Stockholm: Riksidrottsförbundet.

Garland, D. 2014. “The welfare state: A fundamental dimension of modern government". European Journal of Sociology 55 (3): 327- 364. doi: 10.1017/S0003975614000162

Green, M. 2012. “Advanced liberal government, sport policy, and 'building the active citizen"'. In Sport and Neoliberalism: Politics, Consumption, and Culture, edited by Andrews, D.L. and Silk, M.L., 38-56. Philadelphia: Temple University Press.

Hartmann, D. 2016. Midnight Basketball. Race Sports, and Neoliberal Social Policy. Chicago: The University of Chicago Press.

Hartmann, D. and Kwauk, C. 2011. "Sport and development: An overview, critique, and reconstruction". Journal of Sport and Social Issues 35 (3): 284-305. doi: 10.1177/0193723511416986

Harvey, J., Lévesque, M., and Donnelly, P. 2007. "Sport volunteerism and social capital”. Sociology of Sport Journal 24 (2), 206-223. doi: 10.1123/ssj.24.2.206

Heinemann, K. 2006. "Sport and the welfare state in Europe". European Journal of Sport Science 5 (4): 181-188. doi: 10.1080/17461390500344347

Houlihan, B., Bloyce, D. and Smith, A. 2009. "Editorial: Developing a research agenda in sport policy”. International Journal of Sport Policy 1 (1): 1-12. doi: 10.1080/19406940802681186

Larsson, B., Letell, M. and Thörn. H., 2012. "Transformations of the Swedish welfare state: Social engineering, governance and governmentality: An introduction". In Transformations of the Swedish Welfare State, edited by Larsson, B., Letell, M. and Thörn, H., 3-22. New York: Palgrave MacMillan. 
Lawson, H.A. 2005. "Empowering people, facilitating community development and contributing to sustainable development: The social work of sport, exercise and physical education programs”. Sport, Education and Society 10 (1): 135-160. doi: 10.1080/1357332052000308800

Morgan, H. 2013. "Sport volunteering, active citizenship and social capital enhancement: What role in 'big society'?” International Journal of Sport Policy and Politics 5 (3): 381-395. doi: 10.1080/19406940.2013.764542

Mouffe, C. 2005. On the political. London: Routledge.

Nichols, G. 2007. Sport and Crime Reduction: The Role of Sports in Tackling Youth Crime. London: Routledge.

Norberg J.R. 2011. "A contract reconsidered? Changes in the Swedish state's relation to the sports movement". International Journal of Sport Policy and Politics 3: 311-325. doi: 10.1080/19406940.2011.596157

Österlind, M. 2017. "Strävan efter samhällsförbättring”. PhD diss., Umeå University

Parnell, D., Pringle, A., Widdop, P. and Zwolinsky, S. 2015. "Understanding football as a vehicle for enhancing social inclusion: Using an intervention mapping framework". Social Inclusion 3(3): 158-166. doi: $10.17645 /$ si.v3i3.187

Parton, N. 1996. "Social Theory, Social Change and Social Work: An Introduction". In Social Theory, Social Change and Social Work, edited by Parton, N., 4-18. London: Routledge.

Richardson Jr., J.B. 2012. "Beyond the playing field: Coaches as social capital for innercity adolescent African-American males". Journal of African American Studies 16 (2): 171-194. doi: $10.1007 / \mathrm{s} 12111-012-9210-9$

Rose, N. 1999. Powers of Freedom: Reframing Political Thought. Cambridge: Cambridge University Press.

Sherry, E., Schulenkorf, N. and Chalip, L. 2015. "Managing sport for social change: The state of play”. Sport Management Review 18 (1): 1-5. doi: 10.1016/j.smr.2014.12.001

Silk, M.L. and Andrews, D.L. 2012. "Sport and the neoliberal conjuncture: Complicating the consensus". In Sport and Neoliberalism. Politics, Consumption, and Culture, edited by Andrews, D.L. and Silk, M.L., 1-22. Philadelphia: Temple University Press.

Spaaij, R. 2009. "Sport as a vehicle for social mobility and regulation of disadvantaged urban youth". International Review for the Sociology of Sport 44 (2-3): 247-264. doi: $10.1177 / 1012690209338415$

Stenling, C. (2015). "The Drive for Change: Putting the Means and Ends of Sport at Stake in the Organizing of Swedish Voluntary Sport”. PhD diss., Umeå University.

Theebom, M., Haudenhuyse, R. and De Knop, P. 2010. "Community sports development for socially deprived groups: a wider role for the commercial sports sector? A look at the Flemish situation". Sport in Society 13 (9): 1392-1410. doi: 10.1080/17430437.2010.510677

Verdot, C. and Shut, P.O. 2012. "Sport and social inclusion: The political position vs. practices". European Journal for Sport and Society 9 (3): 203-227. doi: 10.1080/16138171.2012.11687897

Webb, S.A. 2006. Social Work in a Risk Society: Social and Political Perspectives. New York: Palgrave MacMillan. 
i This article is a partially based on, and contain an elaboration and synthetization of, themes introduced in Ekholm 2016. 